\title{
Naphthalene biodegradation by alkaliphilic Pseudomonas aeruginosa EGDS2
}

\author{
Mohamed I. Abou-Dobara, Ahmed K.A. El-Sayed*, Yahya T. Khalaf \\ Botany and Microbiology Department, Faculty of Science, Damietta University, New Damietta, Damietta, Egypt.
}

Received: 5 January 2017 /Accepted: 18 March 2017

* Corresponding author: akaelsayed@du.edu.eg

\begin{abstract}
A naphthalene degrading bacterium was isolated from diesel contaminated soil in Damietta County, Egypt. It is identified as Pseudomonas aeruginosa strain EGDS2 based on classical and 16S rDNA sequence techniques. P. aeruginosa EGDS2 was highly able to degrade naphthalene in addition to benzene, toluene, catechol, and xylene. The normalize dioxygenases of P. aeruginosa EGDS2 responsible for naphthalene degradation was optimized for producing the maximum activity. The results revealed that the maximum dioxygenases activity was after 48 hours at pH 9.0 and 30oC. The best nitrogen source was sodium nitrate, and $7 \mathrm{~g} / \mathrm{l}$ of naphthalene was the optimum concentration for highest dioxygenases activity. The promising yield of dioxygenases of P. aeruginosa EGDS2 makes this isolate very useful for bioremediation of aromatic hydrocarbon pollutants.
\end{abstract}

Keywords: Naphthalene, dioxygenase, Pseudomonas aeruginosa, optimization.

\section{Introduction}

Biodegradation of aromatic compounds is a nature method to remove pollutants in the environments where it has been known for a long time that microorganisms can degrade pollutants in different environments under aerobic or anaerobic condition. Polycyclic aromatic hydrocarbons (PAHs) likes naphthalene, anthracene and phenanthrene are among largest industrial chemicals produced, with production figures of millions of tons per year. These compounds are used as fuels, which in nature is of great environmental concern due to their toxic, mutagenic, and carcinogenic properties.

Lower-molecular-weight PAHs, such as naphthalene and phenanthrene, are relatively easy to degrade, and able to be metabolized by a large number of different microorganism strains (Cerniglia, 1992). In soil environments, degradation of PAHs is strongly affected by the low bioavailability of the compounds, as they have only limited water solubility and tends to be sorbet strongly to particularly organic matter. Biodegradation using microorganisms is usually the preferred and major route of PAH removal from contaminated environments because of its 
cost effectiveness and complete cleanup (Pothuluri and Cerniglia, 1994).

The first step of naphthalene degradation by bacterial metabolism, is the formation of the corresponding 1,2-dihydrodiol in the optically pure cis-(1R, 2s)-dihydroxy-1,2dihydro naphthalene form. The cis-relative stereochemistry is characteristic of the bacterial degradation in contrast to the mammalian metabolism, which yields trans diols. This reaction in bacteria is carried out by normalized dioxygenases enzymes which also can oxidize indole to indigo dye (Ensely et al., 1983) that can be easily monitored spectrophotometry.

Previous research on this issue has been reported the effectiveness of many bacterial strains with regard to aromatic degradation, and the most commonly bacteria are Pseudomonas sp. (Sorensen et al., 2010) like P. putida and P. fluorescens (Shim and Yang, 2002 and 2006; Shim et al. 2002 and 2005) and P. aeruginosa (Kim et al. 2003). B. pumilus was one of the consortia members which were able to degrade PAH present in the crops rhizosphere contaminated with field PAH (Ma et al. 2010).

There is a need for more information on microbial degradation of polycyclic aromatic hydrocarbons in Egypt. In this work, we report the isolation and identification of naphthalene degrading Pseudomonas aeruginosa from Egyptian contaminated soils with diesel. Also, optimization of normalized dioxygenases enzymes activity was considered.

\section{Materials and methods}

\section{Isolation of naphthalene-metabolizing bacteria}

$10 \mathrm{~g}$ of diesel contamination soil samples around irrigation pumps (at Damietta, Egypt) were used as inoculum. Samples were placed into sterile polythene bag then immediately brought to the laboratory. Each sample was mixed well to insure sample homogeneity then added to $100 \mathrm{ml}$ of sterile distilled water. Leave it for $15 \mathrm{~min}$ in shaker (200 rpm) at room temperature. $1 \mathrm{ml}$ of soil suspension used as inoculum in modified mineral salt agar medium (Ortiz et al., 2005) consisted of ( $\mathrm{g} / \mathrm{l}): 0.6 \mathrm{KH}_{2} \mathrm{PO}_{4}$;
$2.4 \quad \mathrm{~K}_{2} \mathrm{HPO}_{4} ; \quad 1.5 \quad \mathrm{MgSO}_{4} \cdot 7 \mathrm{H}_{2} \mathrm{O} ; 0.15$ $\mathrm{CaSO}_{4} \cdot 2 \mathrm{H}_{2} \mathrm{O} ; \quad 0.03 \quad \mathrm{FeSO}_{4} \cdot 7 \mathrm{H}_{2} \mathrm{O} ; \quad 3.0$ $\left(\mathrm{NH}_{4}\right)_{2} \mathrm{SO}_{4}, \mathrm{pH} 7$ and modified by adding trace element $1 \mathrm{ml}$ per liter of (Beauchop and Elsden, 1960). In addition to naphthalene $(2 \mathrm{~g} / \mathrm{l})$, other hydrocarbon compounds (benzene, toluene, catechol, and xylene) were added separately to the previous medium were after autoclaving the pervious medium.

\section{Identification of naphthalene degradation isolate}

\section{Classical Identification}

The identification based on morphological, physiological and biochemical characters including standard method of Bergey's manual (Palleroni, 1984).

\section{Molecular identification}

This identification was based on the $16 \mathrm{~S}$ rDNA sequencing. Genomic DNA was extracted by phenol/chloroform extraction followed by ethanol precipitation according to Ausubel et al (2003).

The extracted DNA was subjected to PCR amplification condition following Eden $e t$ al., (1991) using the 16S rDNA bacteria universal primers: $27 \mathrm{~F}$ (5ेAGAGTTTGATCMTGGCTCAG-3) and 1492R (5GGTTACCTTGTTACGACTT-3). The PCR product was sequenced by an automated sequencer sequencing (Macrogen co. Korea) using the same pervious primers.

Blast (Altschul et al., 1990 and 1997) was performed to obtain the DNA sequence match with the best similarities with other related 16S rRNA genes on database. Pairwise and multiple DNA sequence alignment were carried out using CLUSTALW multiple sequence alignment programme version 1.82 (Thompson et al., 1994). Bootstrap neighbor joining tree was generated using MEGA version 4 (Tamura et al., 2007). The Saccharomyces cerevisiae was used as an out group strain.

\section{Assay of normalized dioxygenases activity}

Bacterial cells were cultured on previously described mineral salt broth medium 
supplemented with naphthalene as the only carbon source and incubated at $30^{\circ} \mathrm{C}$ with shaking $(200 \mathrm{rpm})$. After $48 \mathrm{hr}, 1 \mathrm{ml}$ of medium was harvested at $4^{\circ} \mathrm{C}$ and cells were washed with phosphate buffer $(\mathrm{pH}=7.2)$ by centrifugation $(1 \mathrm{~min}$ at $14,000 \mathrm{rpm})$. The cells were resuspended in $1 \mathrm{ml}$ menial salt broth medium without naphthalene. The sample was then immediately shaking in water bath at $30^{\circ} \mathrm{C}$ and the reaction was initiated by adding 5 $\mu 1$ of $100 \mathrm{mM}$ indole in $N, N-$ dimethlylformamide (DMF). The formation of indigo was measured spectrophotometrically at $\mathrm{OD}_{600}$ as a function of time where control contains all reaction components except indole. The enzymes activity was defined as the initial rate of indigo formation normalized to the protein content of the sample (Wooa et al., 1999). The protein concentration in each sample was determined by Lowry et al., (1951).

\section{Optimization of normalized dioxygenases} from $P$. aeruginosa EGDS2

Pseudomonas aeruginosa EGDS2 was grown on previously modified MSM supplement with naphthalene for incubation period varied from $24 \mathrm{hrs}$ to 120hrs.The naphthalene concentration were $1,2,3,4,5,6,7,8,9$ and 10 gram per liter was applied. A range of $\mathrm{pH} 4-10$ was studied. Also temperature 25, 30, 35, 40 and $45^{\circ} \mathrm{C}$ were conducted.

Effect of supplementary nitrogen source on dioxygenases activity by replacing ammonium sulfate in the MSM according to equivalence with ammonium chloride, ammonium nitrate, ammonium dihydrogen phosphate, sodium nitrite, sodium nitrate, beef extract, yeast extract, peptone and tryptone, thus were applied at $30^{\circ} \mathrm{C}$ and $\mathrm{pH}$ 9.0 for 48 hours.

All experiments were run in parallel triplicates and the results analysis in IBM SPSS statistics version 22

\section{Results}

Isolation and identification of naphthalene metabolizing bacterial isolate

The bacterial isolate that had the ability to grow and metabolizing naphthalene $(2 \mathrm{~g} / \mathrm{l})$ on modified mineral salt agar medium was identified according to Bergey's manual. Its morphological characteristics and biochemical reactions are listed in Table 1 indicated that the bacterial isolate could be identified as Pseudomonas aeruginosa strain EGDS2.

The $16 \mathrm{~S}$ sequence alignment showed that the EGDS2 isolate was highly similar to the other strains of $\mathrm{P}$. aeruginosa present in the data base. The highest similarity reached more than $99 \%$ with $\mathrm{P}$. aeruginosa S3 (KX911719), P. aeruginosa FA-HZ1 (CP017353), P.aeruginosa L15 (KX832717), P. aeruginosa M1 (KX495190) and P. aeruginosa ATCC15692 (CP017149) as indicated in the phylogenetic tree analysis (Figure 1).

Table 1. Morphological characteristics and biochemical reactions for identification of the $\mathrm{P}$. aeruginosaEGDS2 isolate.

\begin{tabular}{|lc|}
\hline \multicolumn{1}{|c|}{$\begin{array}{c}\text { Morphological, physiological } \\
\text { and Biochemical properties }\end{array}$} & Reactivity \\
\hline \multicolumn{2}{|c|}{ Morphological characteristics } \\
\hline Gram Stain & -ve \\
Shape & Rods \\
Spore formation & $-\mathrm{ve}$ \\
\hline \multicolumn{2}{|c|}{ Physiological characteristics } \\
\hline Air condition & Aerobic \\
Oxidase & $+\mathrm{ve}$ \\
Catalase & $+\mathrm{ve}$ \\
Indole & $-\mathrm{ve}$ \\
Voges-Proskauer & $-\mathrm{ve}$ \\
Citrate utilization & $+\mathrm{ve}$ \\
Casein Hydrolysis & $+\mathrm{ve}$ \\
Starch Hydrolysis & $-\mathrm{ve}$ \\
Gelatin Liquefaction & $+\mathrm{ve}$ \\
Nitrate reduction & $+\mathrm{ve}$ \\
H2S production & $-\mathrm{ve}$ \\
Deamination of Phenylalanine & $-\mathrm{ve}$ \\
Urease activity & $+\mathrm{ve}$ \\
\hline \multicolumn{2}{|c|}{ Utilization of sugars } \\
\hline Glycerol & $+\mathrm{ve}$ \\
Arabinose & $+\mathrm{ve}$ \\
Xylose & $+\mathrm{ve}$ \\
Galactose & $+\mathrm{ve}$ \\
Lactose & $-\mathrm{ve}$ \\
Mannose & $+\mathrm{ve}$ \\
Fructose & $+\mathrm{ve}$ \\
Glucose & $+\mathrm{ve}$ \\
\hline \multicolumn{2}{|c|}{} \\
\hline
\end{tabular}




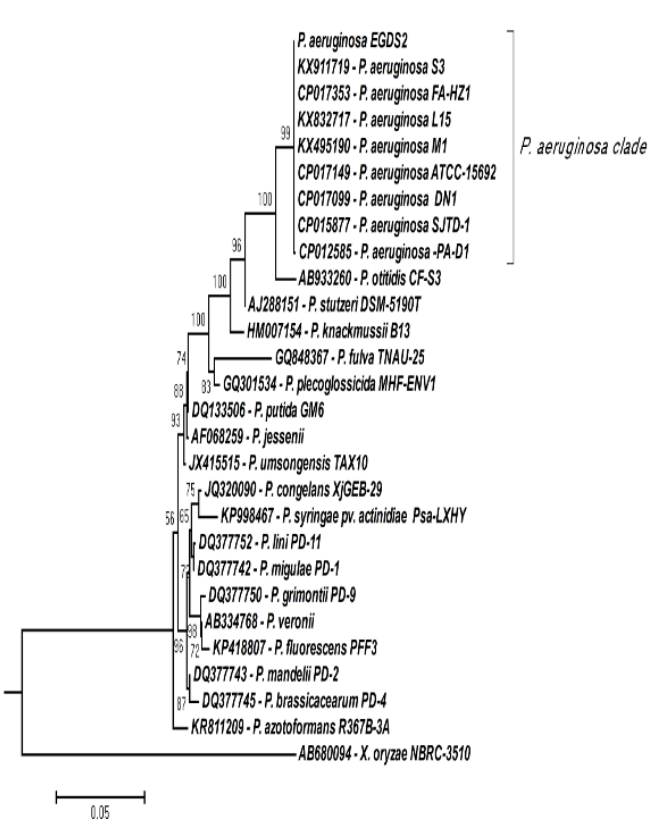

Figure 1. Phylogenetic tree analysis based on the 16S rDNA sequence alignment for $\mathrm{P}$. aeruginosa EGDS2 with some other related and Pseudomonas species which possessed the best similarity. The 16S rDNA sequence of Xanthomonas oryza(AC:AB680094) was used as out-group to root the tree.

Optimization of normalized dioxygenases activity from $P$. aeruginosa EGDS2

\section{Effect of incubation period}

To ascertain the effects of cultivation time on the normalized dioxygenases enzymes activity, $P$. aeruginosa EGDS2 was cultivated for different periods. The results revealed that the activity of the dioxygenase of $P$. aeruginosa EGDS2 was increased progressively until the second day (48 hours) that reached the maximum activity $\quad(55.4905 \mu \mathrm{g} \quad$ indigo/mg protein/min) at the first minute, and then it decreased dramatically to $27.7452 \mu \mathrm{g}$ indigo/mg protein/min after two minutes. It then stabled to the average $20.16841 \mu \mathrm{g}$ indigo/mg protein/min till ten minutes (Figure 2.A). On the other hand, the first 24 hours showed steady dioxygenases activity with approximate average $7.4140 \mu \mathrm{g}$ indigo/mg protein/min. After 72 hours, it decreased to approximate average 3.3439 $\mu \mathrm{g}$ indigo/mg protein/min of enzymes activity, and then it lowered 0.5163 and $0.2434 \mu \mathrm{g}$ indigo/mg protein/min at 96 and 120 hours, respectively (Figure 2.B).

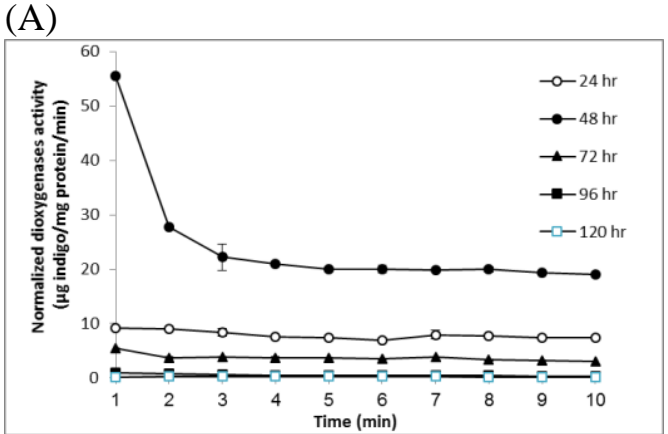

(B)

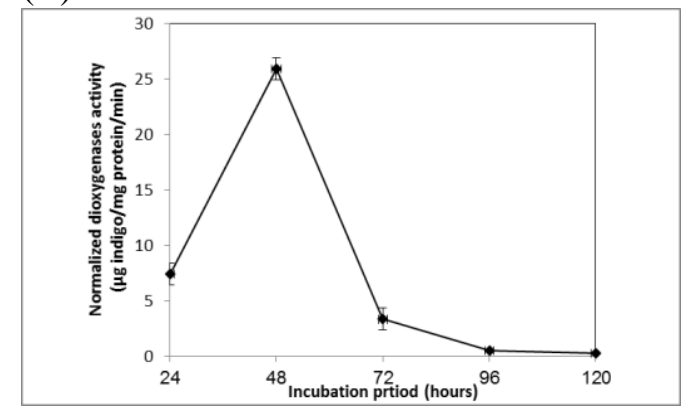

Figure 2. (A)The effect of incubation period on normalized dioxygenases enzymes activity from $P$. aeruginosa EGDS2, the activity was measured for ten minutes intervals. (B) The activity of normalized dioxygenases after 5 minutes for each incubation period.

\section{Effect of temperature}

The maximum activity of dioxygenases of P. aeruginosa EGDS2 was optimum at $30^{\circ} \mathrm{C}$ with enzymes activity $50.9494 \mu \mathrm{g}$ indigo/mg protein/min. The highest value of normalized dioxygenases activity was recorded at the first minute $(115.11 \mu \mathrm{g}$ indigo/mg protein $/ \mathrm{min}$ ) then decreased to $57.55 \mu \mathrm{g}$ indigo/mg protein $/ \mathrm{min}$ in the $2 \mathrm{nd}$ minute (Figure 3.A). Total average of normalized dioxygenases activity was decreased to minimum at $40^{\circ} \mathrm{C}(11.8 \mu \mathrm{g}$ indigo/mg protein $/ \mathrm{min})$ and $45^{\circ} \mathrm{C}(5.08 \mu \mathrm{g}$ indigo/mg protein/min) (Figure 3.B).

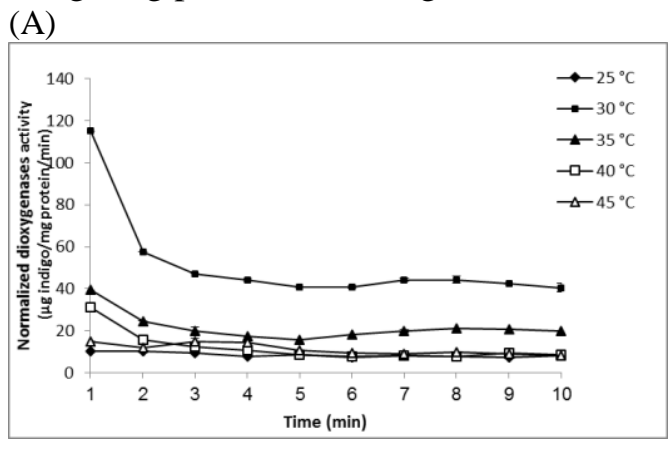


(B)

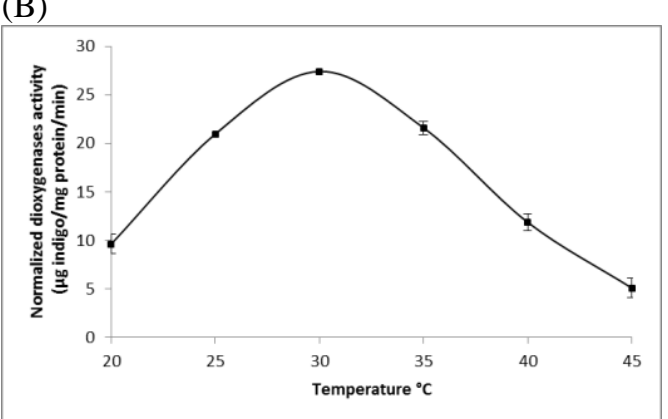

Figure 3. (A) The effect of temperature on normalized dioxygenases activity produced by P. aeruginosa EGDS2, the activity was measured for ten minutes intervals. (B) The activity of normalized dioxygenases after 5 minutes of different temperatures.

\section{Effect of $p H$}

The $\mathrm{pH} 9.0$ was the optimum for dioxygenases activity $(106.7601 \mu \mathrm{g}$ indigo/mg protein/min) followed by $\mathrm{pH} 10$ (53.7 $\mu \mathrm{g}$ indigo/mg protein/min). After one minute, the activity decreased gradually till 10 minutes (Figure 4.A). The minimal activity was recorded at $\mathrm{pH} 4(2.09 \mu \mathrm{g}$ indigo/mg protein/min) and $\mathrm{pH} 5(6.73 \mu \mathrm{g}$ indigo/mg protein/min) as represented in Figure 4.B.

(A)

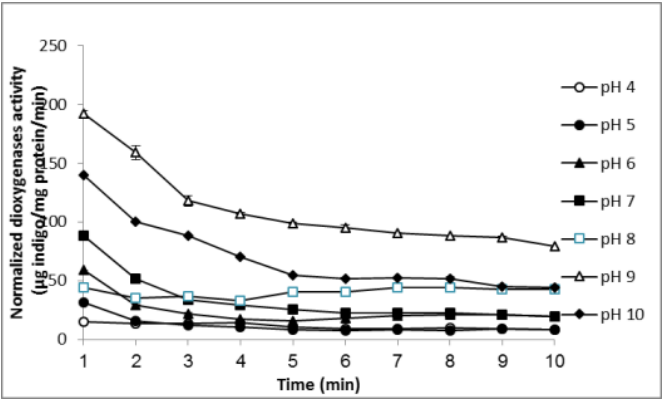

(B)

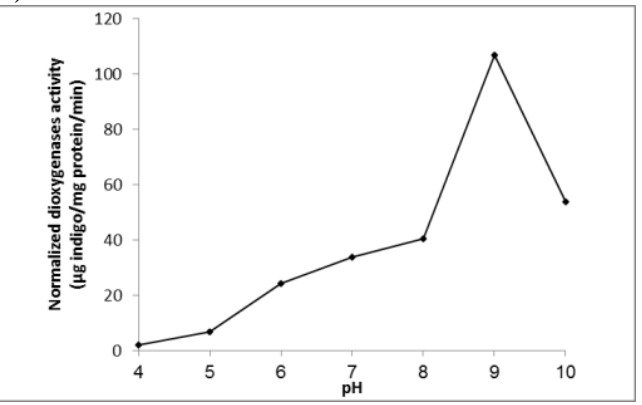

Figure 4. (A) The effect of $\mathrm{pH}$ on normalized dioxygenases activity produced by $P$. aeruginosa EGGS2, the activity was measured for ten minutes intervals. (B) The activity of normalized dioxygenases at 5 minutes for different pHs.

\section{Effect of different nitrogen sources}

Interestingly the best nitrogen source of dioxygenases activity of $\mathrm{P}$. aeruginosa EGGS2 was NaNO3 giving the highest activity value $(301 \mu \mathrm{g}$ indigo/mg protein/min) at the $1 \mathrm{st}$ minute, and then decreased to $189.9 \mu \mathrm{g}$ indigo/mg protein/min and $133.8 \mu \mathrm{g}$ indigo/mg protein/min after two and three minutes, respectively. Afterword, it reached $74.4 \mu \mathrm{g}$ indigo/mg protein/min after 10 minutes (Figure 5.A). The other nitrogen sources exhibited lower normalized dioxygenases activity compared with $\mathrm{NaNO}_{3}$ (Figure 5.B). The next lower activity was recorded using $\mathrm{NH} 4 \mathrm{H} 2 \mathrm{PO} 4$ at one minute $(59 \mu \mathrm{g}$ indigo/mg protein $/ \mathrm{min}$ ), then decreased to $29.5 \mu \mathrm{g}$ indigo/mg protein $/ \mathrm{min}$ after 2 minutes.
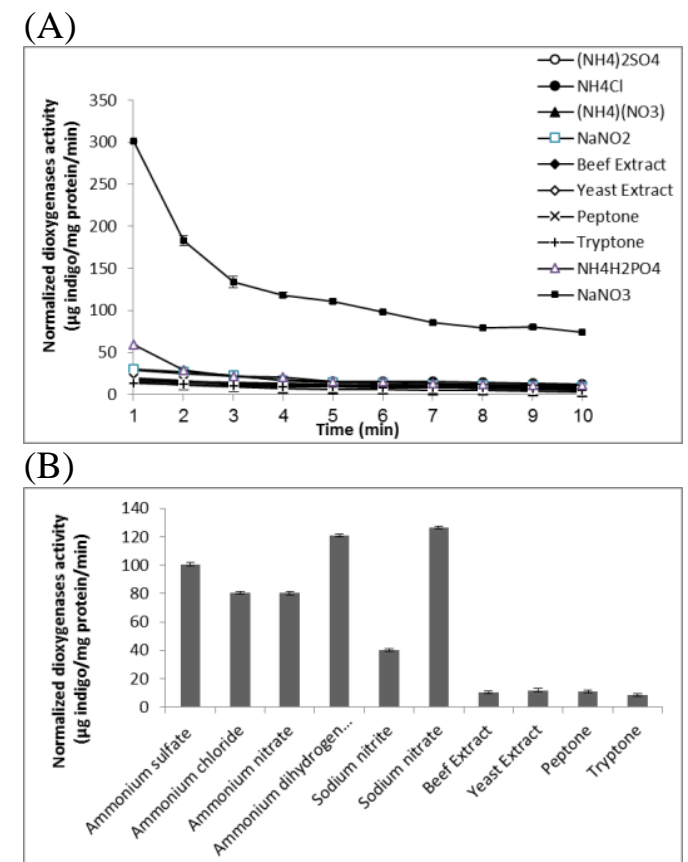

Figure 5. (A) The effect of different nitrogen sources on normalized dioxygenases activity produced by $\mathrm{P}$. aeruginosa EGDS2, the activity was measured for ten minutes intervals. (B) The activity of normalized dioxygenases at 5 minutes for each nitrogen sources.

\section{Effect of naphthalene concentration}

Generally, the best naphthalene concentration for dioxygenases activities was at $7 \mathrm{~g} / 1$ followed by $8 \mathrm{~g} / \mathrm{l}$. At the $1^{\text {st }}$ minute, $8 \mathrm{~g} / 1$ recorded the highest enzymes activity $(64.2 \mu \mathrm{g}$ indigo/mg protein $/ \mathrm{min})$ followed by $7 \mathrm{~g} / \mathrm{l} \quad(61.2 \mu \mathrm{g}$ indigo/mg protein/min) (Figure 6.A). The enzymes activity then decreases to minimal at $1 \mathrm{~g} / 1$ 
(10.22 $\mu \mathrm{g}$ indigo/mg protein/min) and $10 \mathrm{~g} / \mathrm{l}$ (17.7 $\mu \mathrm{g}$ indigo/mg protein/min) as showed in Figure 6.B.

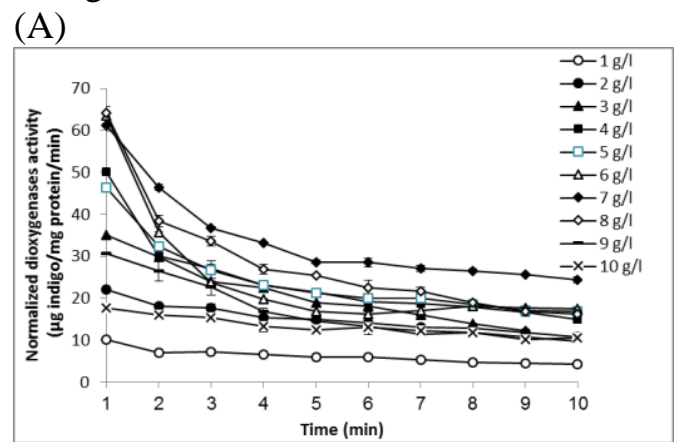

(B)

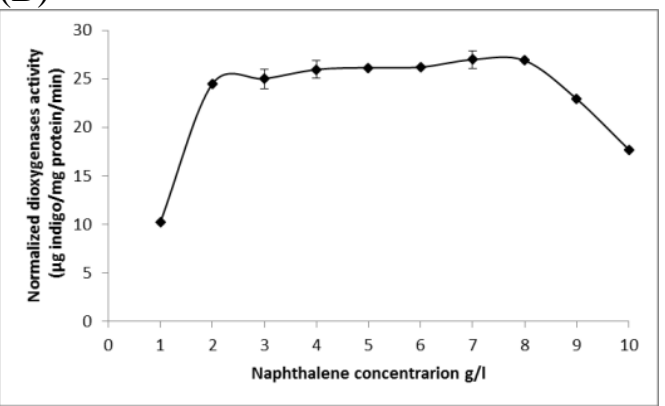

Figure 6. (A) The effect of different naphthalene concentrations on normalized dioxygenases activity produced by $\mathrm{P}$. aeruginosa EGDS2, the activity was measured for ten minutes intervals. (B) The activity of normalized dioxygenases at 5 minutes for naphthalene concentration.

\section{Discussion}

Identification of naphthalene degradation bacterium was performed using the morphological and physiological properties in combination molecular tools of $16 \mathrm{~S}$ rRNA gene sequencing. The bacterial isolate is a Gram negative rods, nonendospore forming, catalase and oxidase positive refers to be identified as Pseudomonas aeruginosa according to Bergey's Manual of Systematic Bacteriology (Palleroni, 1984). It was widely known that the genus Pseudomonas is a very diverse group of bacteria including many different species (Wagner et al., 2008), so this might need additional modern tools such as DNA sequencing for confirmation their identification. Consequently, the molecular identification based on 16S rDNA sequence alignment of the $P$. aeruginosa EGDS2 gave a high similarity, reached to $99 \%$, with other $P$. aeruginosa strains present on the database. Also, the $16 \mathrm{~S}$
rDNA sequencing based phylogenetic tree revealed that it is clustered in the same clade with the other $P$. aeruginosa strains and grouped away from the other species of the genus Pseudomonas. Furthermore, it is not totally related to the genus Xanthomonas.

Environmental factors such as temperatures $\mathrm{pH}$ and nutrient composition had been reported to have some important influences on an enzymes activity by bacterial organism. According to the above records, this investigation is made to enhance the maximum activity of normalized dioxygenases produced by the isolated $P$. aeruginosa EGDS2. The optimization of their cultural conditions such as cultivation period, optimum $\mathrm{pH}$, temperature, the best nitrogen sources and optimal naphthalene concentrations, of the isolate were studied. The maximum activity of normalized dioxygenases by $P$. aeruginosa EGDS2 was determined at 48 hours. Further increase in the incubation period beyond the optimum incubation time resulted in decrease in the enzymes activity. Our result was quite identical with optimal time line production of catechol 2,3-dioxygenase produced by Pseudomonas sp. strain ZJF08 (Zou et al., 2007). This probably because the enzymes might be expressed highly at the late log phase of the bacterial growth which in case of Pseudomonas sp. is at about 48 hours, then the activity is dramatically dropped when started the stationary phase.

The maximum dioxygenases activity of $P$. aeruginosa EGDS2 was observed at $30^{\circ} \mathrm{C}$. In agreement with our result, Wojcieszynska et al., (2011) indicated that catechol 2,3-dioxygenase from Stenotrophomonas maltophilia KB2 possessed extremely high activity at $30^{\circ} \mathrm{C}$. Most of normalized dioxygenases are produced at $35^{\circ} \mathrm{C}-40^{\circ} \mathrm{C}$ by many mesophilic bacteria. For example, catechol 1,2-dioxygenase from $P$. putida $\mathrm{N} 6$ and $B$. cereus was optimally active at $35^{\circ} \mathrm{C}$ (Guzik et al., 2011; Jayanthi and Hemashenpagam, 2015).

Most of natural environments usually have $\mathrm{pH}$ values 5.0 to 9.0. Consequently, this range is considered also optimal for biodegradation of hydrocarbon by microorganisms (Fatajeva et al., 2014). Pseudomonas sp. ZJF08 and P. putida N6 
expressed catechol 2,3-dioxygenase and 1,2-dioxygenase, respectively, with optimal activity at $\mathrm{pH} 7.5$ (Zou et al., 2007; Guzik et al., 2011), while B. cereus possessed optimally active catechol 1,2dioxygenase at $\mathrm{pH}$ 7.0 (Jayanthi and Hemashenpagam, 2015). Degradation of BTEX compounds by alkaliphilic Pseudomonads species had been rarely reported (Hirota et al., 2011). Catechol 2,3dioxygenaseobtained from Pseudomonas sp. HB01 was maximally active at $\mathrm{pH} 10.5$. The dioxygenase of $P$. aeruginosa EGDS2 strain was highly active at $\mathrm{pH} 9.0$, which considered tending to be alkaliphilic enzyme.

The nitrogen source is one of the limiting factors for a bacterial growth and its enzymatic activities. $\mathrm{NaNO}_{3}$ was the best nitrogen source for dioxygenases from the $P$. aeruginosa EGDS2 strain compared with the other tested sources. Nigam et al., (1998) reported that the maximum growth of $P$. putida UUC-1 and another two bacterial strains PNA-2 and PNC-2 were on medium supplemented with naphthalene and $\left(\mathrm{NH}_{4}\right)_{2} \mathrm{SO}_{4}$ rather than $\mathrm{KNO}_{3}$ and $\mathrm{NH}_{4} \mathrm{Cl}$. On the other hand, $\mathrm{NH}_{4} \mathrm{Cl}$ was the best nitrogen source for degrading benzene, toluene and xylene when B. cereus isolate was tested (Jayanthi and Hemashenpagam, 2015). Our strain ( $P$. aeruginosa EGDS2) behaved differently as it utilized $\mathrm{NaNO}_{3}$ as the best nitrogen source for degrading the naphthalene over the other tested nitrogen sources.

$P$. aeruginosa EGDS2 was able to utilize naphthalene perfectly, as its maximum dioxygenases activity was recorded at $7 \mathrm{~g} / \mathrm{l}$ naphthalene concentration. Though there was slight decline beyond $7 \mathrm{~g} / \mathrm{l}$ of naphthalene, the enzyme activity still fine. This decrease might be associated with metabolizing capacity of the isolate and toxicity of naphthalene. Aromatic hydrocarbon BTEX compounds (Benzene, Toluene, Ethylbenzene and Xylene) upon reaching certain concentrations can inhibit the microbial activity due to complex micro- and macro- level interactions (Jo et $a l .$, 2008). Naphthalene dioxygenase from P. putida $\mathrm{G} 7$ was improved before $56 \mathrm{ppm}$ of naphthalene concentration, but decreased at $240 \mathrm{ppm}$ and higher (Chang et $a l .$, 2015). Two bacterial strains PNA-2 and PNC-2 were compared with $P$. putida
UUC-1as all gave maximum growth at $2 \mathrm{~g} / \mathrm{l}$ of naphthalene (Nigam et al., 1998). $P$. putida N6 strain degradedphenol completely up to concentrations of $10 \mathrm{mM}$, while hydroquinone and vanilic acid were degraded up to concentrations of $5 \mathrm{mM}$. On the other hand, The higher concentration above $9 \mathrm{mM}, 11 \mathrm{mM}$, and $14 \mathrm{mM}$, for benzoic acid, protocatecuic acid, 4hydroxybenzoic acid and, respectively, caused the growth inhibition of $P$. putida strain N6 (Guzik et al., 2011). Furthermore, $P$. putida strain F1 could not completely degrade Benzene at concentration above $380 \mathrm{mg} / \mathrm{l}$ and Toluene above $420 \mathrm{mg} / \mathrm{l}$ (Hamed et al., 2003).

In conclusion, The $P$. aeruginosa EGDS2 isolate exhibited highly derivative properties towards aromatic hydrocarbon including naphthalene. Its dioxygenases tends to be alkaliphilic and produced maximally after 48 hours at $30^{\circ} \mathrm{C}$. This isolate is a promising strain for bioremediation of multi aromatic hydrocarbon pollutants. Further studies would be considered for identification and characterization of the types of those dioxygenases including DNA sequencing for their genes.

\section{References}

Altschul SF, Gish W, Miller W, Myers EW, Lipman DJ, (1990) Basic local alignment search tool. J. Mol. Biol., 215: 403-410.

Altschul SF, Madden TL, Schäffer AA, Zhang J, Zhang Z, Miller W, Lipman DJ, (1997) Gapped BLAST and PSI-BLAST: a new generation of protein database search programs. Nucleic Acids Res., 25: 33893402 .

Ausubel FM, Brent R, Kingston RE, Moore DD, Seidman JG, Smith JA, Struhl K, (2003) Current Protocols in Molecular Biology. Chapter 2: Preparation and Analysis of DNA. John Wiley and Sons, Inc; ringbou edition.

Beauchop T, Elsden SR, (1960) The growth of organisms in relation to their energy supply. J. Gen. Microbiol., 23: 457-469.

Cerniglia CE, (1992) Biodegradation of polycyclic aromatic hydrocarbons. Biodegradation, 3: 351-368.

Chang SY, Liu XG, Ren BQ, Liu B, Zhang K, Zhang H, Wan Y, (2015) Effects of LB broth, naphthalene concentration, and 
acetone on the naphthalene degradation activities by Pseudomonas putida G7. Water Environ. Res., 87(1): 61-67.

Eden PA, Schmidt TM, Blakemore RP, Pace NR, (1991) Phylogenetic Analysis of Aquaspirillum magnetotacticum Using Polymerase Chain Reaction-Amplified 16S rRNA-Specific DNA. Int J Syst Bacteriol., 41 (2): 324-325.

Ensely BD, Ratzkin BJ, Osslund TD, Simon MJ, Wackett LP, Gibson DT, (1983) Expression of naphthalene oxidation genes in Escherichia coli: Results in the biosynthesis of indigo. Science, 222: 167169.

Fatajeva E, Gailiute I, Paliulis D, Grigiškis S, (2014) The use of Acinetobacter sp. for oil hydrocarbon degradation in saline waters. Biologija, 60 (3): 126133.

Guzik U, Gren I, Hupert-Kocurek K, Wojcieszynska D, (2011) Catechol 1,2dioxygenase from the new aromatic compounds e Degrading Pseudomonas putida strain N6. International Biodeterioration \& Biodegradation, 65: 504-512.

Hamed TA, Bayraktar E, Mehmetoğlu T, Mehmetoğlu Ü, (2003) Substrate interactions during the biodegradation of benzene, toluene and phenol mixtures. Process Biochemistry, 39(1): 27-35.

Hirota K, Yamahira K, Nakajima K, Nodasaka Y, Okuyama H, Yumoto I, (2011) Pseudomonas toyotomiensis sp. nov., a psychrotolerant facultative alkaliphile that utilizes hydrocarbons. Int. J. Syst. Evol. Microbiol., 61(8): 1842-1848.

Jayanthi R, Hemashenpagam N, (2015) Optimization of $\mathrm{BH}$ medium for efficient Biodegradation of Benzene, Toluene and Xylene by a Bacillus cereus. Int. J. Curr. Microbiol. App. Sci., 4(10): 807-815.

Jo MS, Rene ER, Kim SH, Park HS, (2008) An analysis of synergistic and antagonistic behavior during BTEX removal in batch system using response surface methodology. Journal of Hazardous Materials, 152 (3): 1276-1284.

Kim SB, Park CH, Kim DJ, Jury WA, (2003) Kinetics of benzene biodegradation by Pseudomonas aeruginosa: parameter estimation. Environ. Toxicol. Chem., 22: 1038-1045.

Lowry OH, Rosebrough NJ, Farr AL, Randall RJ, (1951) Protein Measurement with the Folin Phenol Reagent. J. Biol. Chem, 193: 265-275.
Ma B, Chen H, He Y, Xu JM, (2010) Isolations and consortia of PAH-degrading bacteria from the rhizosphere of four crops in PAH contaminated field. In: 19th World Congress of Soil Science. Soil Solutions for a Changing World. Brisbane, pp 63-66.

Nigam P, Banat IM, Marchant R, (1998) Degradation of naphthalene by bacterial cultures. Environment International, 24(5): 671-677.

Ortiz I, Velasco A, Revah S, (2005) Effect of toluene as gaseous cosubstrate in bioremediation of hydrocarbon-polluted soil. Journal of Hazardous Materials, B131 (2006) 112-117.

Palleroni NJ, (1984) Genus I Pseudomonas. In Krieg and Holt (Editors), Bergey's Manual of Systematic Bacteriology. 1st Ed., Vol. 1, The Williams and Wilkins Co., Baltimore. pp. 141-199.

Pothuluri J, Cerniglia C, (1994) Microbial metabolism of polycyclic aromatic hydrocarbons. In Biological Degradation and Bioremediation Toxic Chemicals. G.R. Chaudry, (ed). London, Chapman and Hall, pp. 92-124.

Shim H, Shin E, Yang ST, (2002) A continuous fibrous-bed bioreactor for BTEX biodegradation by a co-culture of Pseudomonas putida and Pseudomonas fluorescens. Adv. Environ. Res., 7: 203216.

Shim H, Yang ST, (2002) BTEX removal from contaminated groundwater by a co-culture of

pseudomonas putida and pseudomonas fluorescens immobilized in a continuous fibrous-bed bioreactor. J. Chem. Technol. Biotechnol., 77: 1308-1315.

Shim H, Yang ST, (2006) Kinetics of BTEX biodegradation by a coculture of Pseudomonas putida and Pseudomonas fluorescens. J. Environ. Eng. Manage., 16: 309-317.

Sorensen SR, Johnsen AR, Jensen A, Jacobsen CS, (2010) Presence of psychrotolerant phenanthrene-mineralizing bacterial populations in contaminated soils from the Greenland High Arctic. FMEs. Microbiol. Lett., 305: 148-154.

Tamura K, Dudley J, Nei M, Kumar S, (2007) MEGA4: Molecular Evolutionary Genetics Analysis (MEGA). Mol. Biol. Evol., 24(8): 1596-1599. 
Thompson JD, Higgins DG, Gibson TJ, (1994) CLUSTAL W: improving the sensitivity of progressive multiple sequence alignment through sequence weighing, position specific gap penalties and weight matrix choice. Nucleic Acids Res., 22: 46734680.

Wagner J, Short K, Catto-Smith AG, Cameron DJS, Bishop RF, (2008) Identification and Characterisation of Pseudomonas 16S Ribosomal DNA from Ileal Biopsies of Children with Crohn's Disease. PLoS. ONE, 3(10): e3578. doi:10.1371/journal.pone.0003578.

Wojcieszynska D, Hupert-Kocurek K, Gren I, Guzik U, (2011) High activity catechol 2,3- dioxygenase from the cresols e Degrading Stenotrophomonas maltophilia strain KB2. International Biodeterioration \& Biodegradation, 65: 853-858.

Wooa H, Sanseverinoa J, Coxa C, Robinsona K, Sayler G, (1999) The measurement of toluene dioxygenase activity in biofilm culture of Pseudomonas putida F1. Journal of Microbiological Methods, 40: 181-191.

Zou Y, Wei J, Jiang T, Gao W, Ma Y, Wei D (2007) Characterisation of thermostable catechol 2,3-dioxygenase from phenanthrenedegrading Pseudomonas sp. strain ZJF08. Ann. Microbiol., 57: 503-508.

عنوان البحث: التحلل البيولوجي للنفثلين بواسطة Pseudomonas aeruginosa EGDS2 المحبة للقلوية

محمد إسماعيل أبو دبارة، أحمد قاسم عبد الصمد السيد، يحيي طاهر خلف

قسم النبات والميكروبيولوجي، كلية الطوم، جامعة دمياط

تم عزل البكتريا المحللة للنفتالين من التربة الملوثة بالديزل من محافظة دمياط ، مصر ـ تم تعريف عزلة

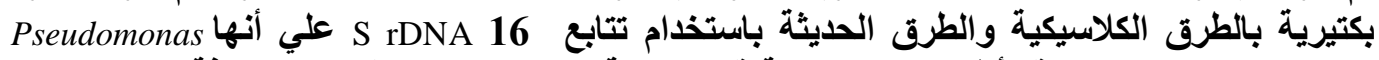
aeruginosa EGDS2,

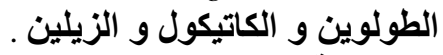

تم دراسة الظروف المثلي لإنتاج أفضل نشاط للإنزيمات المسئولة عن عملية تكسير النفالين المسماه normalize dioxygenases

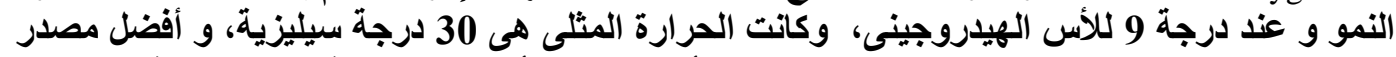

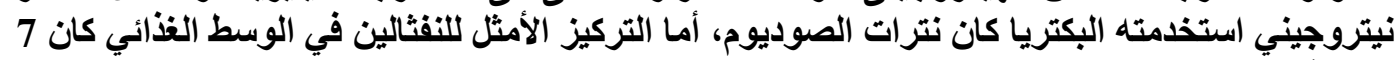

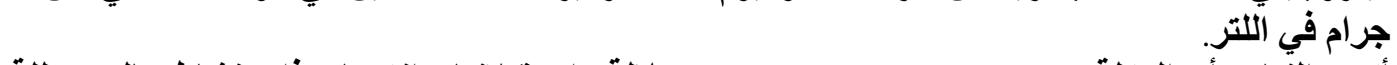
أكلت النتائج أن العزلة P. aeruginosa EGDS2 تعتبر سلالة واعدة لإنتاج إنزيمات ذات نثاط عالى محلة للمواد الهيدوكربونية مما يؤهل استخامها تباعا للتخلص من التلوث البيئي الناتج عن تلكت المركبات. 